\title{
PRELIMINARY DESCRIPTION OF A PALEONISCOID FISH FROM THE LATE PALEOZOIC OF BRAZIL
}

by

\author{
DAVID H. DUNKLE ${ }^{1}$
}

U. S. NATIONAL MUSEUM

and

\author{
BOBB SCHAEFFER
}

\section{THE AMERICAN MUSEUM OF NATURAL HISTORY}

\section{INTRODUCTION}

Only a few fragmentary fish remains have as yet been described from the much debated Gondwanic rocks of Brazil. The complete specimen which comprises the subject of this preliminary note is, therefore, of considerable interest. The fossil, property of the Department of Geology and Paleontology University of São Paulo, was recovered recently from a quarry situated at Conchas, a city in the south-central part of the state of São Paulo. It derived from siltstones of the Corumbatai formation ${ }^{2}$ Stratigraphically, these Corumbatai beds are restricted in distribution to São Paulo and are considered a lateral facies of the Estrada Nova and Rio de Rasto formations of the States of Santa Catarina and Parana. It, therefore, together with the Irati formation constitutes a regional expression of the Lower Permian Passo Dois Series. Ecolo-

(1) Published gy permission of the Secretary, Smithsonian Institution.

(2) O espécime foi encontrado por operários municipais entre os $\mathrm{Km} 199$ e 200 da rodovia Conchas-Botucatu, a 40 metros aquém do ribeirāo dos Lopes, e entregue ao Ginásio Estadual de Conchas. Por intermédio do Prof. Virgilio M. de Souza e do Dr. Sylvio Froes de Abreu, uma das metades do achado foi oferecida ao nosso Departamento, ficando a outra metade no mencionado Ginásio.

Deixamos os nossos agradecimentos pelo alto espírito de compreensāo ao Prof. Virgilio M. de Souza, ao Dr. Sylvio Froes de Abreu, assim como aos cuidadosos operários que perceberam o valor do achado e naturalmente aos Drs. D. Dumple e B. Schaeffer pelo esudo do espécime.

Departamento de Geologia e Paleontologia. 
gically many students, according to Dr. Mendes '3, believe the sediments to have been laid down under some non-marine conditions.

The occurrence of this relatively well preserved and distinctive fossil fish would seem to offer a means of increasing our meager knowledge of the early palaeoichthyolcgic faunas of South America. It is to be sincerely hoped that further search will reveal supplementary materials. These writers are sincerely grateful to Drs. Viktor Leinz and J C. Mendes for arranging to have the specimen sent for study and description. Dr. Mackenzie Gordon, U S. Geological Survey, has been helpful on matters of Brazilian stratigraphy and the photograph and drawings have been prepared, respectively, by Messrs. Floyd B. Kestner and William D. Crockett, Smithsonian Institution.

\title{
ORDER PALEONISCOIDEA
}

\author{
Family Acrolepidae
}

\section{Tholonotus ${ }^{4}$, new genus}

Generic Diagnosis: - Fusiform fishes, with longitudinally arched dorsum and venter of low convexity, attaining a total length not known to exceed $13 \mathrm{~cm}$. and distinctive among other paleoniscoid fishes by virtue of the following combination of characters: Skull between onethird and one-fourth standard body length with low rounded snout, anteriorly situated orbit whose greatest diameter is less than one third the head length, and suspensorium only slightly oblique. Parietal narrow but about one-half as long as the frontal. Frontal somewhat narrower behind than forwardly Postrostral small and broader than long. Dermopterotic large, obliquely truncated anteriorly but with extended postero-lateral corner Dermosphenotic produced anteriorly above orbit to articulate with a deep, narrowly crescentic nasal. Epitemporal and separate supra-orbital absent. Four infra-orbital elements, the anteroinferior one of which overlaps the maxillary to obtain the oral border and abut on the anterorostral. Suborbitals present. Maxillary with short, high but dorsally truncated postorbital plate. Dentition weak or absent. Dorsal preoperculum angulated anteriorly but displaying a

(3) Im littoris.

(4) Named in allusion to the arched dorsum. 


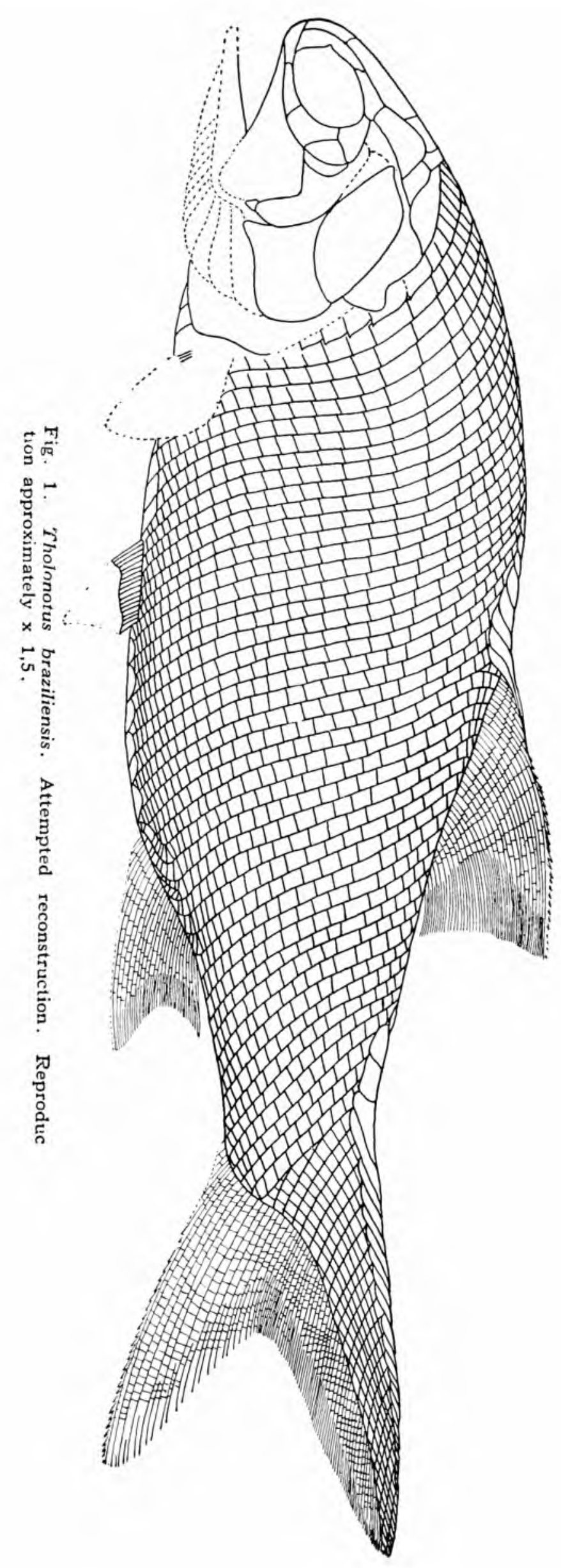





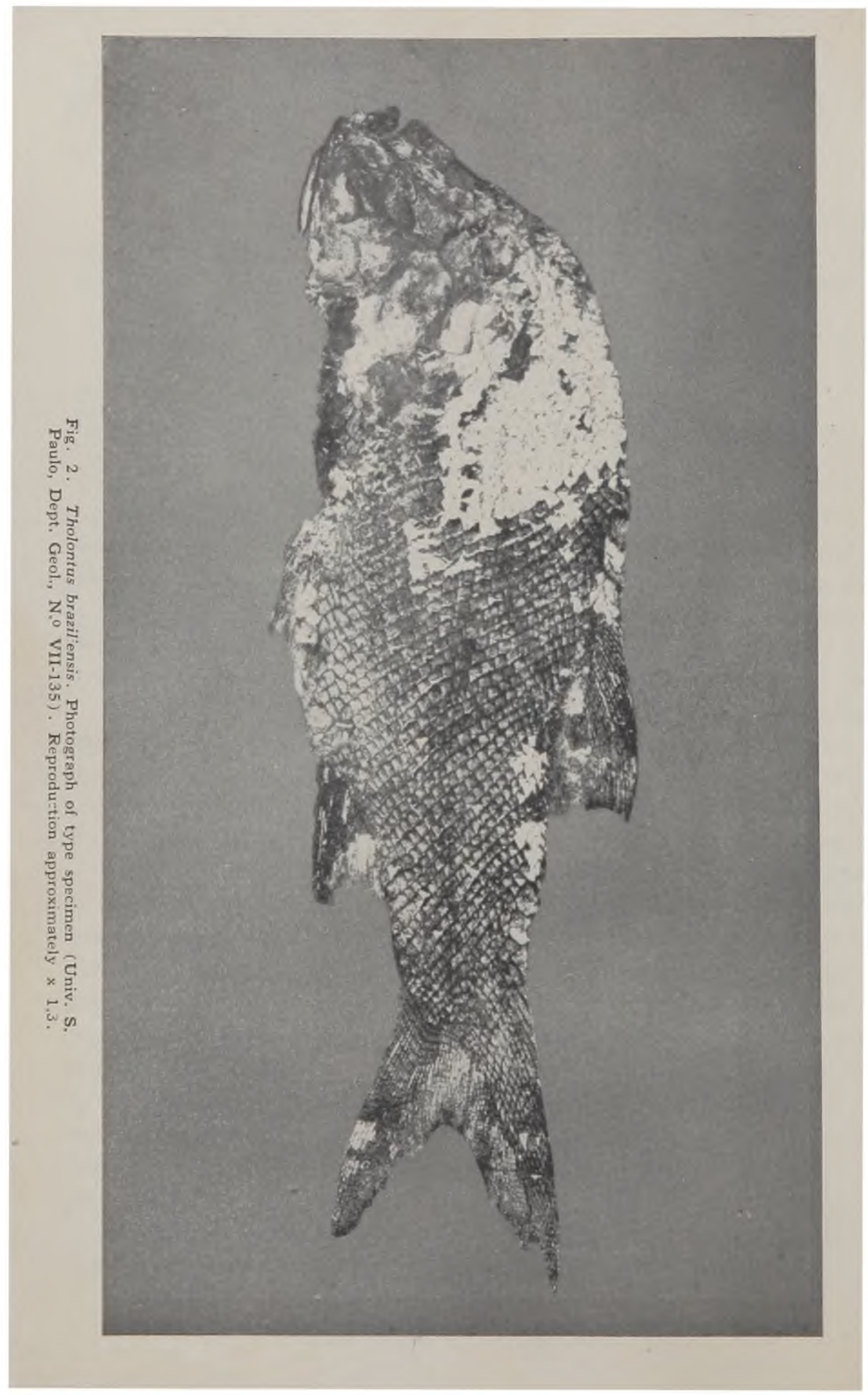



continuous curve posteriorly. Ventral preoperculum or quadrato-jugal exposed laterally above angle of jaw Opercular bones relatively large; the operculum deeper than suboperculum but less long. Supracleithrum with depth only two-thirds that of operculum. Pelvic fins deeper than long originating below the 1 lth vertical scale row, nearer the pectoral than to the anal and composed of about 17 lepidotrichia. Dorsal fin triangular, with greater base length than height, arising opposite middle of standard body length and composed of about 37 rays. Anal also triangular but deeper than long, originating below posterior extremity of dorsal and composed of no more than 27 rays. Caudal fin deeply cleft, nearly equilobate, and with about 60 rays. Small fulcra present in sequence with enlarged ridge scales and alternating with the tips of anterior undivided rays on all observable fins.

Body completely covered with large thin rhomboidal scales arranged in 46 vertical row which at the bases of the dorsal and anal fins are inverted. Dorsal articular spine well developed at least anteriorly but internal vertical rib poorly defined. Anterodorsal angle somewhat produced and posterior border of many scales pectinated. Majority of scales equilateral although several rows adjacent to lateral line anteriorly much deeper than long and many ventral series with heights less than lengths. Ornamentation confined to anterior trunk region and to scales adjacent to both dorsum and venter in advance of the unpaired fins, and consisting of diagonal ribs. Posteriorly these are reduced near the border of the scales and the intervening grooves represented only by pits.

Genotype. - Tholonotus braziliensis, sp. nov.

Tholonotus braziliensis, sp. nov.

Diagnosis. - The same as for the genus (the only species)

Holotype. - Impression of a complete fish, No. VII-135, Dept. Geol. Paleont., Fac. Fil. Cien. Letr., Univ. S. Paulo; from the Corumbetai formation at Conchas, São Paulo, Brazil.

\section{DESCRIPTION}

Except for the ganoine covering of some of the head bones and for small patches of scales, little of the original osseous tissues of this 
fish are preserved. The specimen, thus, is comprised chiefly of a flattened impression of the right side of a moderately sized individual exposed on a reddish, fine-grained shaly matrix. Details of the body squamation and fins are generally excellent. Unfortunately, the head and anterior bod part suffered some twisting and distortion during preservation. As a result the outlines and relationships of many skull elements remain either obscure or completely unknown and some modification in the accompanying, tentative restorations undoubtedly will be necessary when supplementary materials are obtained in the future.

The fish, displaing a maximum body depth at a level in advance of the dorsal fin of approximately four-tenths the standard length, is of stoutly fusiform habit. In profile, the dorsum is rather highly arched while the venter is of low convexity. The head, in length from snout to posterior limit of the operculo-subopercular suture, measures between onethird and one-fourth the standard body length and is indicated to ba relatively wide. No accurate observation of its depth can be made, although this dimension probably does not equal the length. The snout is blunt and rounded. The orbits are very large and are situated so far forward that their anterior borders lie practically in the same transverse plane of the snout extremity. The suspensorium shows only a slight obliquity. However, the gape of the subterminal mouth is long. The dentition, if indeed not completely absent, must be assumed weak. The dorsal fin arises opposite the midpoint of the standard length, behind the plane of origin of the pelvics but well in front of that of the anal. The caudal fin, supported by a stout caudal pedicle, is completely heterocercal, deeply cleft and almost equilobate.

The transverse series of extrascapular elements is not clearly discernible but at least two and possibly three pairs of bones appear to be present. Twice as wide as long, each of the lateral pair occupiss an area about equal to that covered by the more mesially situated plates on each side. The parietals are of irregular outline. Combined they form a quadrangular shield whose width and greatest observable length are approximately one-half the axial length of the frontal. Each frontal is three times longer than wide. Anteriorly and posterolaterally their margins are embayed for articulation with, respectively, the postrostral and dermopterotic. The latter emarginations cause the frontals to appear somewhat broader anteriorly than behind. Their median suture is gently undulating. 


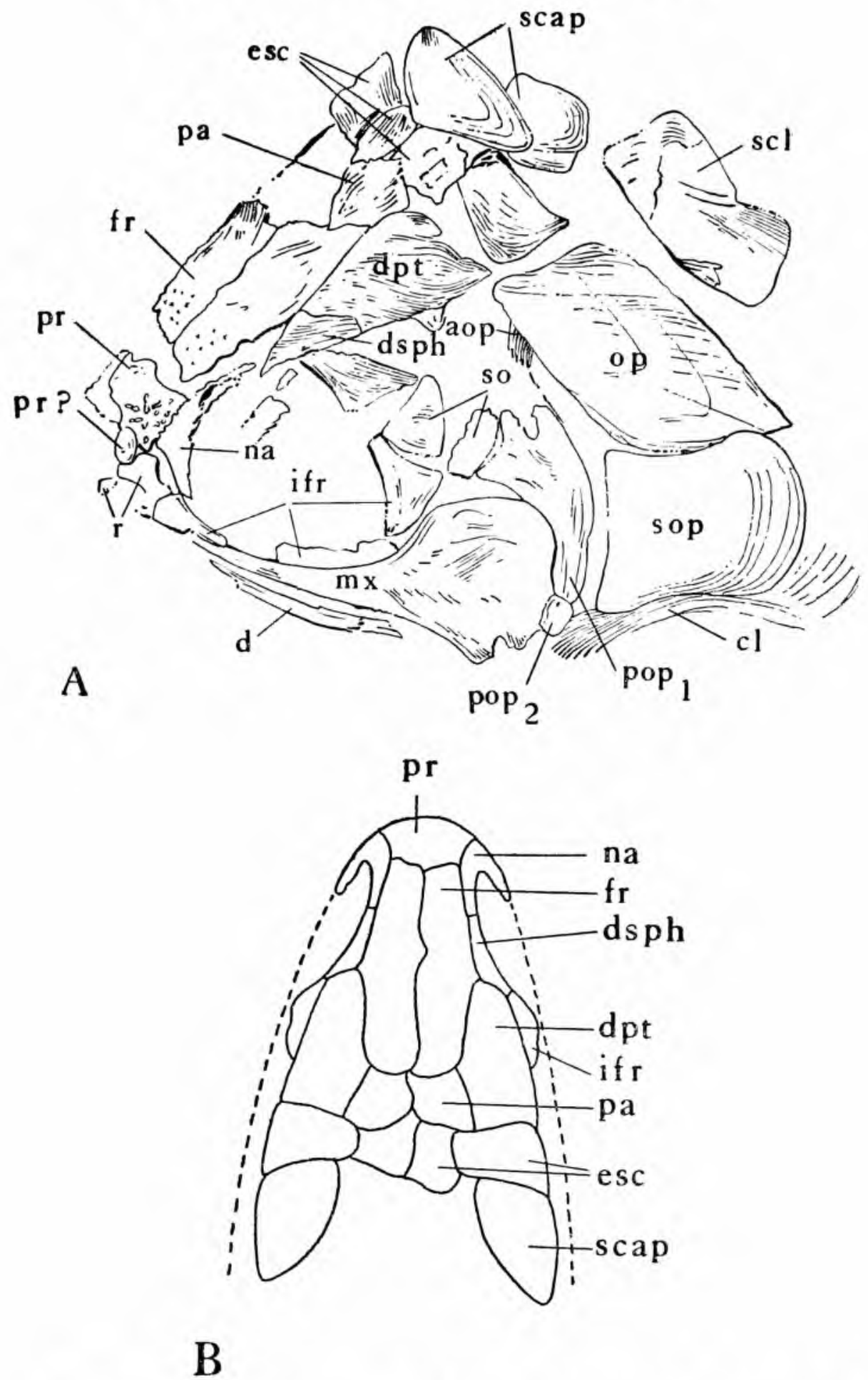

Fig. 3. Tholonotus braziliensis. A. Outline drawing of the bones of the obliquely crushed type skull (Univ. S. Paulo, Dept. Geol., N..$^{\circ}$ VII-135) as preserved. Approximately $\times 2,5$. B. Beconstruction of skull in dorsal aspect. Approximatelv x 2.9 .

\section{ABREVIATIONS}

aop, antoperculum; cl., cleithrum; d, dentary; dpt, dermopterotic; dsph, dermosphenotic; esc, extrascapulars; fr, frontal; ifr, circumorbitals; mx, maxillary; na, nasal; op, operculum; pa, parietal; pop 1 e 2, respectively, dorsa! preoperculum and ventral preoperculum or quadratojugal; pr, postrostral; pr?, questioned separate anterior pustrostral; r, rostral; scap, suprascapular; scl, supra--leithrum; so, suborbital; and sop, suboperculum. 
The dermopterotic (supratemporal-intertemporal), with a length only a little less than that of the frontal, is relatively very large. The bone tapers from the its greatest width posteriorly to an obliquely truncated anterior margin. Succeeding it anteriorly is a long narrow element here identified as the dermosphenotic. If returned to normal position this latter bone would appear to touch remnants of bone tissue which are considered to be a postero-lateral extension of the nasal since they seemingly receive the supra-orbital sensory canal from the frontal. As in Boreosomus (Nielsen, 1942; Lehman, 1952; etc.) the dermosphenotic (supra-orbito-dermosphenotic) and the narrcw crescentic nasal constitute the major portion of the dorsal and anterior orbital border

Despite evidences for presumably all component elements, the bones of the snout are difficult to interpret. The impression of the postrcstral, although probably lacking the left lateral margin, is unusual in displaying a rectangular outline with appreciable less length than breadth. These proportions, coupled with the shallow natural curvature kept by the bone, are indicative of the blunt roundness of the rostral extremity of the head. As seen in internal aspect, a small ovate and ganoine filled impressicn overlaps the antero-inferior margin of the postrostral. This, displaced to the right of the median line and with a concentric ornamentation in marked contrast to the elongated tubercular sculpture of the postrostral, has the appearance of a distinct element. However, it well may prove a fragmented median process of the postrostral which extends forward between the anterior rostral elements. Roughly triangular in outline, these meet in the median line and their bases comprise the antero-median segment of the oral border Above, their concave medial margins must have contacted the small median bone, the postrostral, and possibly provided a portion of the anterior narial border Laterally, their sides touch the anterior edges of the nasals and, excluded from the orbital rim, abut posteriorly onto a bone of the infra-orbital series.

The bones surrounding the orbit posteriorly and ventrally number four and are of rather generalized development. The most posterodorsal one of the series is directly comparable in shape and relationship to the element of Turseodus called by Schaeffer (1952) the post-orbital. It does not project forward parallel to the dermosphenotic above the orbit and, in fact, distinct supra-orbital elements are absent. The antero-inferior bone in the series is long, low, and, passes beneath the ventral extremity of the nasal to articulate with the anterior rostral. As 
preserved, it also would appear to have overlapped the maxilla and to have formed, possibly, a portion of the oral border

Two small impressions of bones occupy the ventral portion of the suborbital bone space between the infra-orbital series and the preoperculum. Suborbital ossicles, thus, were definitely present in the cheek and probably totaled only two on either side.

The preoperculum is represented by two elements on either side, a large dorsal one and a small quadrangular ventral one. The dorsal member displays a marked angulation in the anterior margin. Its posterior border, however, comprises a smooth sweeping arc. The outline of the element, thus, approaches that of the same member in Boreosomus (Nielsen, 1942; Brough, 1933, and Lehman, 1952) and reflects the slight obliquity of the suspensorium. The ventral bone has the same general proportions and relative position as the quadratojugal of Pteronisculus (Nielsen, 1937 and 1942; Lehman, 1952) and the comparable element in Brachydegma termed a preoperculum (Dunkle, 1937) following nomenclature employed by Westoll (1937)
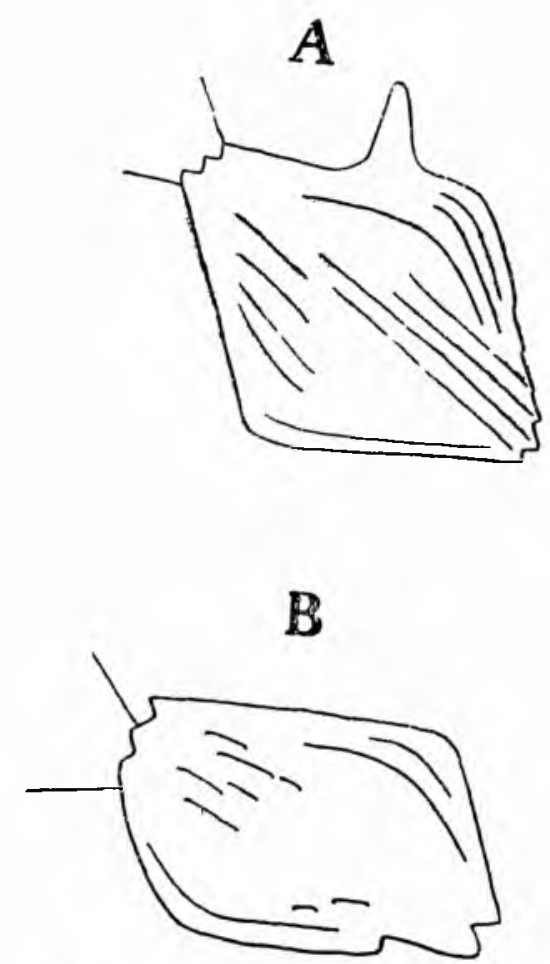

Fig. 4. Tholonotus braziliensis. Outline of scales from (A) flank and (B) caudal pedicles. Reproduction approximately $x 1,6$. 
The maxillary is of the usual characteristic form with low infraorbital and short high postorbital parts. Only an edge of the mandible is preserved but this remnant indicates a robust structure extending from the quadrate region to a level below the anterior margin of the orbit. Careful preparation of the oral border failed to disclose teeth. The margin of the maxillary posteriorly displays problematical evidences of minute pitting and the dentition, if present, must have been very feeble.

The gular and branchiostegal apparatus is not preserved. The suboperculum is a roughly rectangular plate, slightly longer than deep and with a rounded posterior edge somewhat longer than the anterior and with the upper and lower anterior angles somewhat produced. The operculum is larger than the suboperculum. It is one-third deeper than long and all corners are angular except the postero-dorsal one, which is rounded. Immediately anterior to the operculum is a triangular impression with apex directed downward which is probably an antoperculum.

Parts of other head bones can be discerned. These probably pertain for the most part to dermal elements of the palate and left side of the head, but are not sufficiently interpretable for description.

All of the bones of the head are noticeably sculptured, with attenuated striations except on the postrostral, anterior halves of the frontals and preoperculum, which bear wide elongate tubercles. The striations are generally closely set, sinuous, and tend to parallel the main longitudinal body axis. The chief variation in this predominant ornamentation is to be observed on the postero-dorsal surface of the maxillary, the suboperculum, and postero-ventral portion of the operculum. In these areas the ridges are low, separated by broad shallow valleys, and arranged concentrically to the margins of the bones.

Aside from the segment of the supra-orbital sensory canal mentioned above, and preserved as a series of minute pits, no other evidence of the lateral line sensory system of the head has been observed.

The dermal bones of the shoulder girdle, insofar as preserved, are of the usual paleoniscoid type. The post-temporal is a large, triangular element of somewhat greater breadth than length. The bone appears generally smooth with only a few widely spaced concentric striae peripherally. The roughly rectangular supracleithrum is three times deeper than long; extends in an arc parallel to the posterior border of the oper- 
culum; and is traversed by the main lateral line sensory canal of the body On its external surface, anteriorly, are short, widely spaced and oblique striations. Posteriorly, the sculpturing is much finer, and parallels the margin of the bone. The small parts of the cleithrum visible are ornamented with wide concentric striations. Only fragments of a few pectoral fin rays are preserved low on the flank and this appendage, although probably horizontal, remains unknown.

The pelvic girdle and fin are likewise incompletely exposed. The proximal segments of the pelvic show an origin below the llth vertical row of body scales, nearer the pectoral than to the anal. The fin is composed of about 17 closely set, completely articulated and distally bifurcating lepidotrichia. The greatest in height exceeds the base length of the fin.

The dorsal fin of this fish is triangular in profile with a shallow emargination in its posterior border Originating above the 27th vertical row of body scales, it is composed of approximately 37 lepidotrichia. Each of these rays is closely articulated to the base and the individual joints are ornamented with two types of striations: extremely fine short ones extending in oblique dorso-posterior direction from the anterior margin, and two or three widely spaced ones near and paralleling the posterior border The eleventh ray appears to possess the greatest height but its axial length is less than the length of the fin base. Anteriorly, the lepidotrichia progressively diminish in height and are nonbifurcating. Enlarged fulcral scales continuing the dorcal ridge scale series override the six shortest anterior rays. Distally the fulcra are of more moderate size, alternate with the tips of succeding rays, and probably do not extend to the extremity of the anterior border of the fin. All of the rays behind the eleventh are divided.

Although smaller, and one-third deeper than long, the anal fin is similarly triangular and acuminate in outline. It originates below the 26 th vertical scale row, cpposite the posterior portion of the dorsal. The characters of the anal lepidotrichia, which number no more than 27 , are the same as those in the dorsal fin. The longest observable ray is the 5th. Fulcra are of moderate size but their arrangement is unknown.

The caudal fin is completely heterocercal, deeply cleft and nearly equilobate. The lepidotrichia, numbering in excess of 60, apparently lack the ornamentation of those of the dorsal and anal fins but are otherwise similar: closely set, jointed to the base and distally branching. The dor- 
sal border of the body axis is set with approximately 30 enlarged ridge scales and attenuated, unpaired fulcra. Ventrally, the anterior 8 rays are not bifurcated and the forward margin of this lobe is armed with moderately sized fulcra.

The body is entirely covered with rhomboidal scales. These, arranged in only 46 vertical rows between the back margin of the supracleithrum and the well marked caudal inversion, may be considered of relatively large size. The number of scales in each vertical row varies some what because of variation in size, dorsally and ventrally In the trunk region, however, the number would seem to average about 30 . It is not possible to determine how many of these are above and how many below the lateral line. Along the central flank the scales are about as deep as long except immediately behind the pectoral girdle where several rows display outlines whose depth exceeds the length. Both dorsally and ventrally the height in proportion to the length decreases slightly Other noticeable variations in size are the densely crowded minute scales adjacent to the bases of the dorsal and anal fins, and the enlarged ridge scales. In regard to the latter, 4 are seen in front of the dorsal fin; 5 in front of the epichordal lobe of the caudal; a complete series of 6 or 7 between the anale and pelvic and several in advance of the pelvics - which feature is perhaps indicative of a keeled venter and ellipsoidal body section.

The scales appear generally thin with relatively wide anterior overlapped areas and serrate posterior margins. In the abdominal region, at least, their dorsal margins bear a high articular spine and the anterior angles are somewhat produced. The sculpture of the scales consists of striation and is most sharply defined on the anterior, dorsal and ventral body parts. In dispostion the strongest striae extend across the exposed surface of the scale obliquely downward and backward from the anterodorsal angle to terminate in the posterior denticulations near the postero-ventral corner Above this diagonal, broader ridges, curving inside the postero-dorsal corner, tend to parallel the dorsal posterior margins of the scale. In the antero-ventral half of the scale, the ridges more or less parallel the main diagonal ridges, although the lowermost arch backward along the inferior border Few posterior anastomoses of these striations are to be observed. On the central flank and posteriorly, the diagonal striae progressively disappear Only the few ridges paralleling the dorsal and ventral margins maintain their distinction and the then generally smooth postero-ventral area is marked only by pits. The preservation of 
the scales is not conducive to histological preparation. Unsatisfactory sections display only the enamel and cosmine layers. The enamel layer is entire but is penetrated by canals or pits whose basal relation with the cosmine canals is unknown. The cosmine canal system at least in part is composed of densely set concentric vessels connected with a radial network. The dentinal dentrites are everywhere extremely dense and reminiscent of the Amblypterus scale figured in frontal section by Aldinger (1937, p. 216)

\section{REMARKS}

For frequently expressed reasons (Aldinger, 1937; Nielsen, 1942; Schaeffer, 1952; and Wilson, 1953 among others), which need not be repeated here, no current classification of the paleoniscoid fishes is entirely satisfactory In consequence, the determination of the relationships of new as well as many long know representatives of the order present perplexing problems. The allocation of Tholonotus is not excepted from these general difficulties, despite the fact that the form is rather well revealed in superficial structure.

Tholonotus displays characteristic ordinal features, and insofar as known, lacks any distinctive "specialization" It has been considered sufficient, therefore, to limit search for phyletic affinities to the central stock of "normal" paleoniscoids. This latter, encompassing the majority of recognized genera, is a diverse assemblage. Although variously treated in the familial sense by different workers, the included families (after Romer, 1945, p. 579) of greatest pertinence to this discussion would appear to be the Rhadinichthyidae, Elonichthyidae, Paleoniscidae (s. str., Aldinger, 1937), Pygopteridae, Acrolepidae, Amblyteridae, Scanilepidae, and Boreolepidae. In compariscns of Tholonotus with these groups, it must be noted that either a vertical suspensorium or the tendency in such a direction has developed independently a number of times. Further, many of the groups include genera with a high-backed body form. On the basis of other single and combined criteria commonly employed taxonomically within the order, however, Tholonotus can be distinguished from all except the Amblyteridae and Acrolepidae. Unfortunately both of these are considered to have derived from the Elonichthyidae and at the present time can be distinguished from that family only within broad overlapping limits. 
The family Elonichthyidae was first defined by Aldinger (1937, p. 204) From the terms of this diagnosis Tholonotus differs as follows: a less prominent rostrum; a weaker dentition; a less oblique suspensorium; the shape of the frontal and absence of an epitemporal; the configurations and proportions of the opercular elements; and a more nearly equilobate caudal fin. Such structural variations in many cases have received wide acceptance as valid generic differences. Their value in family diagnoses, however, remains unknown. These problematical significances are further obscured by the fact that of the assigned members of the family, which range in age from the Mississippian to Permian, lamentably few are known in detail. For instance, in the original family definition, skull structure was based solely on Elonichthys caudalis (Watson, 1928) Aldinger was well aware of the unrestrictive nature of his diagnosis and, in fact (ibidem, p. 206), noting previously observed variation between several species of Elonichthys (Traquair, 1877-1907, pp. 47-92; Woodward, 1891, pp. 487-501) further suggested that this single genus alone probably included representatives of other families. The subsequent critical study of $E$. serratus and E. pulcherrimus by Moy-Thomas and Dyne (1938, p. 459-462) dramatically substantiates the magnitude of structural diversification and denotes the very great amount of supplemental study which will be necessary before any solution of the problems involved in the taxonomy of the family is possible.

Aldinger (1937, p, 205 and 215) included the genera Amblyterus and Westollia (= Lepitopterus, White and Moy-Thomas, 1940) in his family Elonichthyidae but, because of marked differences and lack of detailed corroborative evidence, proceeded to characterize them as a discreet group (of unnamed and undesignated taxonomic rank) within that family Romer (1945, p. 579) referred Amblyterus and several other genera to a family Amblyteridae. It is regrettable that none of the assigned genera have been critically studied by current criteria. The phyletic status of such a grouping would be therefore exceedingly difficult to establish at this time. There is, nevertheless, a long precedent for recognizing the "amblyterids" as a distinctive morphologic type of paleoniscoid fish, even though the sources of this precedent (Troschel, 1897; Traquair, 1877; Pohilg, 1892; Sauvage, 1890, 1893 and 1895; and Westoll, 1937), among others, suggest another arbitrary family complex of structurally "convergent" forms. Tholonotus agrees in all essential points with the two best 
available but gross characterizations of the "amblyterids" (Traquair, 1877, and Aldinger, 1937)

The family Acrolepidae, as defined by Aldinger (1937, p. 250304 ), includes the genera Watsonichthys, Acrolepis, Acropholis, Plegmolepis, Reticulolepis, Hyllingea, Boreosomus ( Diaphorognathus), Acrorhabdus, Ptycholepis, and, tentatively, Stegotrachelus. Most of these allocations have received rather general acceptance. Exceptions are the reference by Romer (1945, p. 579) of Stegotrachelus to the Rhadinichthyidae and removal by Brough (1939) of Boreosomus and Ptycholepis to a family Ptycholepidae assigned to the order Subholostei. According to subsequent discussion by Nielsen (1942, p. 311-382) there is slight reason for doubting the acrolepid relationship of Boreosomus and Ptycholepis. Thus, a minimum geologic range of the family, as now conceived, from the lower Mississippian through the Jurassic is indicated. Aldinger (ibidem) was unable to present a restrictive diagnosis of the family because of the marked differences in dermal bone patterns of the skulls, body forms, and fins displayed by the genera distributed through such a long history The separation of the Acrolepidae from the Elonichthyidae would appear to have been based principally on the distinctive scale structure possessed commonly by all the assigned genera.

The detailed scale histology of Tholonotus remains unknown and the significances of this character which was of such importance in the family diagnosis by Aldinger (ibidem) will be discussed below. In all other general features, as listed by the original author, however, Tholorotus agrees. As a result of the marked morphologic differences between the genera noted above, three subgroups were recognized within the family and the structural variation attributed in large part to progressive phyletic change. Chief among these listed are: (1) change in the suspensorium from very oblique in the oldest forms to nearly vertical in the youngest; (2) change in the operculum from orignally narrower than the suboperculum to wider than the latter bone; (3) dentition strong in the oldest to weak or absent in the youngest; (4) unpaired fins of older genera with posteriorly extended fringelike base to simple triangular shape in younger ones; (5) caudal fin at first completely heterocercal and inequilobate changing to equilobate and abbreviate heterocercal; and (6) scales originally thick but later thin. The attributes of Tholonotus fall well within this range of variation. In fact, the condition of most of the characters listed in the present diagnosis is similar 
in greater or lesser degree to the Boreosomus line of development. Aldinger postulated ancestry of Boreosomus in some small lower Permian acrolepid perhaps close to "Elonichthys" aitkeni. In his phylogenetic tree (ibidem, p. 301) "E." aitkeni was omitted but the line was, with reservation, drawn toward the Acrolepis sedgwicki-A. ortholepis complex. Knowledge of the present writers concerning this particular developmental line is based alone on the restoration of the head of Acrolepis sedgwicki (after Westoll) published by Aldinger (ibidem, p. 262) and the detailed accounts of the morphology of Boreosomus by Nielsen (1942) and Lehman (1952). The characters of Tholonotus most suggestive of this relationship are: (1) general body form and fin shape, developement and position; (2) long, narrow frontal tending to a slightly greater width anteriorly than posteriorly; (3) large, anteriorly truncated dermopterotic; (4) short broad postrostral; (5) reduced or absent dentition; (6) degree of vertical inclination of the suspensorium and consequent reduction in size of the post-orbital portion of the maxillary; (7) distinctive form of the supracleithrum; and (8) relative large size of scales.

Information on scale structure might have been of help in making a precise family allocation of Tholonotus. Its scales, as previously described, display grooves and pits in which the cosmine may have reached the surface through the external ganoine layer in characteristic acrolepid fashion. The few scales of Tholonotus available for sectioning derived from regions of the body in which the ornamentation is reduced of absent. Prepared thin sections were fragmentary and showed only a continuous external ganoine layer The scales of Boreosomus (Nielsen, 1942) range from highly ornamented examples to perfectly smooth ones. Regrettably, Nielsen does not state whether the smooth ones are covered with a continuous ganoine or are devoid of this layer. Although probable, as has been shown in Rhadinichthys (Moy-Thomas and Dyne, 1938), great variation in the scale histology of the Acrolepidae has not yet been demonstrated, and further conjecture on the incompletely revealed condition of Thonotus is useless.

The above discussion emphasizes the very real difficulty in presently distinguishing families of paleoniscoid fishes. Similar difficulties are involved in the distinction between convergence and true phyletic relationship in structural variation. Current knowledge does not permit a precise allocation of Tholonotus. However, on the basis of many detailed 
similarities it is perhaps not unreasonable to tentatively include the genus in the Acrolepidae as that family has been defined by Aldinger and Nielsen. Among this assemblage, Tholontus would appear in a structural stage between those of Acrolepis sedgwicki and Boreosomus. 



\section{REFERENCES}

Aldinger, $\mathrm{H}$.

1937. Permische Ganoid fische aus Ostgrönland. Medd. om Gronland, $102(3), 1-392,105$ figs., 44 pls.

Brough, James.

1933. On a new palaeoniscid genus from Madagascar Ann. Mag. Nat. Hist., (10) 11, 76-87, 2 figs., 1 pl.

1939. The Triassic fishes of Besano, Lombardy, London: British Museum, $X+117,46$ figs., 7 pls.

Dunkle, D. H.

1939. A new palaeoniscid fish from the Texas Permian. Amer. Jour. Sci., 237, 262-274, 2 figs., 1 pl.

Lehman, J-P

1952. Etude complimentaire des Poissons de l'Eotrias de Madagascar Kungl. Svenska Vetens. Hand., F S. 2 (6), 1-201, 48 pls.

Moy-Thomas, J. A. and Dyne, M. B.

1938. The Actinopterygian fishes from the lower Carboniferous of Glencartholm, Eskdale, Dumfriesshire. Trans. Royal Soc. Edinburgh, 49, 437-480, 40 figs., 2 pls.

Nielsen, Eigil.

1936. Some few preliminary remarks on Triassic fishes from East Greenland. Medd. om Gronland, 112 (3), 1-55, 19 figs.

1942. Studies on the Triassic fishes from East Greenland.

I. Glaucolepis and Boreosomus. Palaeozool. Groenl. 1, 1-403, 30 pls.

Pohlig, H.

1892. Altpermische Saurierfährten, Fische und Medusen der Gegend von Friedrichroda. Festschr. 70 Gebustst. R. Leuckarts. 59-64. Leipzig.

Romer, A. S.

1945. Vertebrate Paleontology. Ed. 2, V $+687,377$ figs., Chicago. Sauvage, H. E.

1890. Etudes des Gites Mineraux de la France. Bassinhouiller et Permien de Autun et de Epinac. Fasc. III. Poissons Fossiles. Serv. des topog. sout. France. 
1893. Etudes des Gites Mineraux de la France. Bassinhouiller et Permien de Autun et de Epinac. Fasc. V Poissons Fossiles. Serv. des topog. sout. France.

1895. Note sur quelques Amblypterus du Terrain Permien d'Autun. Bull. Soc. de Hist. Nat. de Autun, 8, 301-307, 1 pl.

Schaeffer, Bobb.

1952. The paleoniscoid fish Turseodus from the upper Triassic. Newark Group. Amer. Mus. Novit. 1581, 1-24, 8 figs.

Traquair, R. H.

1877 On the Agassizian genera Amblypterus, Palaeoniscus, Gyrolepis, and Pygopterus. Quart. Jour. Geol. Soc. 33, 548-578.

1877 The ganoid fishes of the Brilish Carboniferous. Pt. I and III. Paleoniscidae. Paleontogr. Soc., London.

Trosehel, F $\mathrm{H}$.

1857 Beobachtungen über die fische in den eisennieren des Saarbrucken steinkohlengebirges. Verhandl. naturh. Verein. preuss, Rheinlande u. Westphalens, N. F IV, 1-19, 2 pls.

Watson, D. M. S.

1928. On some points in the structure of paleoniscid and allied fish. Proc. Zool. Soc. London, 49-70, 15 figs.

Westoll, T S.

1937 On a remarkable fish from the lower Permian of Autun, France. Ann. Mag. Nat. Hist., (10), 19, 553-578, 7 figs.

White. E. I. and Noy-Thomas, J A.

1940. Notes on the nomenclature of fossil fishes. Pt. II. Homonyms D-L. Ann. Mag. Nat. Hist., (11), 6, 98-103.

Wilson, J . A .

1953. Permian vertelrates from Taylor County, Texas. Journ. Paleont., 27 (3), 45(6-470, 15 figs.

Woodward, A. S.

1891. Catalogue of the fossil fishes in the British Museum. Vol. 2, 1 -xliv $+567,57$ figs., 16 pls. 